\title{
The Reputational Landscape
}

\author{
Charles Fombrun, NYU-Stern School of Business \\ Cees Van Riel, Erasmus University, The Netherlands
}

Welcome to the inaugural double issue of the Corporate Reputation Review. At a time when disciplines are fragmenting into ever-more specialized domains, we are pleased to announce the creation of an integrative medium for research and practice about reputation management. Indeed, the primary purpose of the Review is to provide a forum for research-based discussions about corporate reputations. We expect these conversations to reflect the diversity of academic disciplines that are actively contributing to knowledge in this area, whether grounded in strategic management, organization theory, economics, marketing, communications, accounting, or finance. As such, the Review will assemble emerging scholarship about an area that is proving to be of considerable interest to scholars with widely divergent orientations. In this way, we hope to encourage a closer examination of corporate reputations and thereby stimulate the growth of knowledge about the complex socially constructed environments in which companies operate.

We also intend the Corporate Reputation Review to address the proliferating demands by practitioners for answers to questions about how reputations affect competitive positioning, about how to examine and value corporate reputations, about how to build, maintain, and defend those reputations (Hall, 1992). Many professionals have a vested interest in developing answers to these questions, be they chief executive officers or strategic planners, brand managers or identity specialists, accountants or financiers, heads of public relations, community relations, investor relations, customer relations, or employee relations. In their everyday life, each is deeply involved in managing a company's reputational assets. Yet all too few can identify and provide well-reasoned and defensible answers to questions about corporate reputation and reputational dynamics.

A key purpose of the Corporate Reputation Review, then, is to help remedy that lack. Through conceptual articles, empirical research, case studies of best practice, and occasional book reviews, we hope to draw on the expertise of leading researchers and practitioners concerned with corporate identity and identification, the strategic management of stakeholders, corporate branding, the valuation of intangibles, communication, crisis management, and the socioeconomic analysis of competition.

\section{CORPORATE REPUTATION: A CROSSROADS OF CONVERGING DISCIPLINES}

Although corporate reputations are ubiquitous, they remain relatively understudied (Fombrun, 1996). In part, it is surely because reputations are seldom noticed until they are threatened. In part, however, it is also a problem of definition. According to the 'American Heritage Dictionary' (1970: 600) 'reputation' is 'the general estimation in which one is held by the public'. Yet how does such a definition apply to companies? Who constitutes 'the public' of a company, and what is being 'estimated' by that public? Given the diversity of audiences companies address themselves to, whose perceptions and judgments count the most? Those of investors, employees, 
financial analysts, communities, regulators, CEOs?

The lack of systematic attention to corporate reputations can be traced to the diversity of relevant academic and practitioner literatures that explore different facets of the construct (Fombrun and Rindova, 1996). We point here to six distinct literatures that are currently converging in their emphasis on corporate reputations as key but relatively neglected features of companies and their environments.

\section{The economic view}

Economists view reputations as either traits or signals. Game theorists describe reputations as character traits that distinguish among 'types' of firms and can explain their strategic behavior. Signalling theorists call our attention to the informational content of reputations. Both acknowledge that reputations are actually perceptions of firms held by external observers.

Weigelt and Camerer (1988: 443) point out that '... in game theory the reputation of a player is the perception others have of the player's values ... which determine his/ her choice of strategies'. Information asymmetry forces external observers to rely on proxies to describe the preferences of rivals and their likely courses of action. Consumers rely on firms' reputations because they have less information than managers do about firms' commitment to delivering desirable product features like quality or reliability (Grossman and Stiglitz, 1980; Stiglitz, 1989). Similarly, since outside investors in firms' securities are less informed than managers about firms' future actions, corporate reputations increase investor confidence that managers will act in ways that are reputation-consistent. For game theorists, then, reputations are functional: they generate perceptions among employees, customers, investors, competitors, and the general public about what a company is, what it does, what it stands for. These perceptions stabilize interactions between a firm and its publics.

Signalling theorists concur: reputations derive from the prior resource allocations managers make to first-order activities likely to create a perception of reliability and predictability to outside observers (Myers and Majluf, 1984; Ross, 1977; Stigler, 1962). Since many features of a company and its products are hidden from view, reputations are information signals that increase an observer's confidence in the firm's products and services.

Naturally, then, managers can make strategic use of a company's reputation to signal its attractiveness. When the quality of a company's products and services is not directly observable, high-quality producers are said to invest in reputation-building in order to signal their quality (Shapiro, 1983). Their prior investments in reputation-building allow them to charge premium prices, and may also earn them rents from the repeat purchases that their quality products will generate. In contrast, lowquality producers avoid investing in reputation-building because they do not foresee repeat purchases (Allen, 1984; Bagwell, 1992; Milgrom and Roberts, 1986).

In fact, similar dynamics may operate in the capital and labor markets. For instance, managers routinely try to signal investors about their economic performance. Since investors are more favorably disposed to companies that demonstrate high and stable earnings, managers often try to smooth quarterly earnings and keep dividend pay-out ratios high and fixed, despite earnings fluctuations (Brealy and Myers, 1988). Sometimes companies pay a premium price to hire high-reputation auditors and outside counsel. They rent the reputations of their agents in order to signal investors, regulators, and other publics about their firm's probity and credibility (Wilson, 1985). 


\section{The strategic view}

To strategists, reputations are both assets and mobility barriers (Caves and Porter, 1977). Established reputations impede mobility and produce returns to firms because they are difficult to imitate. By circumscribing firms' actions and rivals' reactions, reputations are therefore a distinct element of industry-level structure (Fombrun and Zajac, 1987).

Reputations are difficult to duplicate because they derive from unique internal features of firms. By accumulating the history of firms' interactions with stakeholders they suggest to observers what companies stand for (Freeman, 1984; Dutton and Dukerich, 1991). Reputations are also externally perceived, and so are largely outside the direct control of firms' managers (Fombrun and Shanley, 1990). It takes time for a reputation to coalesce in observers' minds. Empirical studies show that even when confronted with negative information, observers resist changing their reputational assessments (Wartick, 1992). Therefore, reputations are valuable intangible assets because they are inertial (Cramer \& Ruefli, 1994).

Like economists, then, strategists call attention to the competitive benefits of acquiring favorable reputations (Rindova and Fombrun, 1997). They implicitly support a focus on the resource allocations that firms must make over time to erect reputational barriers to the mobility of rivals (Barney, 1986). Since primary resource allocations also stand to improve organizational performance directly, however, it proves difficult to isolate their unique impact on performance and reputation. This explains why empirical studies have had difficulty untangling a causal ordering: both are produced by the same underlying initiatives (McGuire, Sundgren, and Schneeweiss, 1988; Chakravarthy, 1986).

\section{The marketing view}

In marketing research 'reputation' (often labeled 'brand image') focuses on the nature of information processing, resulting in 'pictures in the heads' (Lippmann, 1922) of external subjects, attributing cognitive and affective meaning to cues received about an object they were directly or indirectly confronted with. 'Objects' in marketing research are predominantly 'products' (beer, detergents, computers), while consumers seem to be the principal 'subject' of analyses.

According to the notions of the Elaboration Likelihood Model of Petty and Cacioppo (1986), information processing results in three layers of elaboration: high, medium and low. A high degree of elaboration of information about an object results in a complex network of meanings chunked in memory, enabling a subject to give a sophisticated description of an object. A low degree of elaboration results in simple descriptions like 'good/bad' or 'attractive/unattractive'. A medium degree of elaboration creates a set of attributes enabling a subject to describe an object in terms of salient beliefs and evaluations (Azjen and Fishbein, 1975; Poeisz, 1988). The degree of elaboration is a consequence of the existing knowledge of an individual, the level of involvement of the subject with the object, and the intensity and integrated nature of the marketing communications (Schultz, Lauterbron and Tannenbaum, 1994) through which a company tries to create an attractive, desirable brand.

Building brand equity requires the creation of a familiar brand that has favorable, strong and unique associations (Keller, 1993). This can be done both through the initial choice of the brand identity (the brand name, the logo) and through the integration of brand identities into the supporting marketing program so that consumers purchase the product or service. 
Companies apply three types of branding strategies (Olins, 1978; Kotler, 1991): individual names for all products without any explicit mention of the company; all products refer to the company, identifying the company name on all products; or combining the company name with the product brand names. Preferences for one of the three branding strategies has to be based on the similarity between the endorser and the inferred product/service. Most marketing literature deals with an endorsement of one brand by another brand in the same product category (image transfer by line extensions, Aaker and Keller, 1990; Park, Milberg and Lawson, 1991), products complementing each other (co-branding, Rao and Ruekert, 1994) or linking organizational associations (eg social responsibility and financial performance) to product associations (Belch and Belch, 1987; Keller and Aaker, 1994). An endorsement will be more successful if consumers perceive similarity between the core brand and its extension (Boush and Loken, 1991).

Umbrella branding (Kapferer, 1992; Dawar, 1993) or more specific 'corporate branding' (all processes that are inclined to enhance the value of the corporate brand, Maathuis and Van Riel, 1996) will be more successful if the information asymmetry between buyer and seller creates an incentive for service providers to capitalize on a firm's reputation and introduce new services for existing customers (Nayyar, 1990); when consumers perceive a high degree of risk acquiring the product/service; and finally, when the endorser's attributes are highly relevant in the context of the intended processes of image transfer (Keller, 1993; Brown and Dacin, 1997).

\section{The organizational view}

To organizational scholars, corporate reputations are rooted in the sense-making experiences of employees. A company's culture and identity shape a firm's business practices, as well as the kinds of relationships that managers establish with key stakeholders. Corporate culture influences managers' perceptions and motivations (Barney, 1986; Dutton and Penner, 1992). Corporate identity affects how managers both interpret and react to environmental circumstances (Meyer, 1982; Dutton and Dukerich, 1991). Shared cultural values and a strong sense of identity therefore guide managers, not only in defining what their firms stand for, but in justifying their strategies for interacting with key stakeholders (Miles and Cameron, 1982; Porac and Thomas, 1990).

Thick cultures homogenize perceptions inside a firm and so increase the likelihood that managers will make more consistent self-presentations to external observers. By creating focal principles, that is, general understanding of the right way of doing things in a firm, thick cultures contribute to the consistency of firms' images with stakeholders (Camerer and Vepsalainen, 1988).

Identity and culture are related. Identity describes core, enduring, and distinctive features of a firm that produce shared interpretations among managers about how they should accommodate to external circumstances (Albert and Whetten, 1985). For instance, a comparative study of Bay Area hospitals showed how each institution responded differently to a strike because of their distinct self-images (Meyer, 1982). A case study of how the Port Authority coped with the problem of homelessness in New York demonstrated how an organization's self-image as a high-quality, firstclass institution played a central role in constraining managers' action to cope with the problem (Dutton and Dukerich, 1991). These reports suggest that firms with strong, coherent cultures and identities are more likely to engage in systematic efforts to influence the perceptions of stakeholders. Managers in such firms will probably 
attend carefully to how their firms' key audiences feel about them (Albert and Whetten, 1985).

\section{The sociological view}

Most economic and strategic models ignore the socio-cognitive process that actually generates reputational rankings (Granovetter, 1985; White, 1981). In contrast, organizational sociologists point out that rankings are social constructions that come into being through the relationships that a focal firm has with its stakeholders in a shared institutional environment (Ashforth \& Gibbs, 1990). Firms have multiple evaluators, each of whom apply different criteria in assessing firms. However, these evaluators interact within a common organizational field and exchange information, including information about firms' actions relative to norms and expectations. Thus, corporate reputations come to represent aggregated assessments of firms' institutional prestige and describe the stratification of the social system surrounding firms and industries (Shapiro, 1987; DiMaggio and Powell, 1983).

Faced with incomplete information about firms' actions, observers not only interpret the signals that firms routinely broadcast, but also rely on the evaluative signals refracted by key intermediaries such as market analysts, professional investors, and reporters. Intermediaries are actors in an organizational field. They transmit and refract information among firms and their stakeholders (Abrahamson and Fombrun, 1992). An empirical study of firms involved in nuclear-waste disposal and photovoltaic cell development demonstrated how in both these industries reputational status depended, not only on structural factors like company size and economic performance, but also on a firm's position in the interaction networks linking firms in each institutional field (Shrum and Wuthnow, 1988).
To sociologists, then, reputations are indicators of legitimacy: they are aggregate assessments of firms' performance relative to expectations and norms in an institutional field. Sociologists point to the multiplicity of actors involved in the process of constructing reputations and their interconnectedness.

\section{The accounting view}

A vocal group of academic accountants has recently acknowledged the insufficiency of financial reporting standards in documenting the value of intangibles. They highlight the widening gap between factual earnings reported in annual statements and the market valuations of companies. They also criticize accepted practice that requires managers to expense research and development (R\&D) activities, advertising, and training expenses-activities which strategists recognize as critical enhancements of firms' actual and perceptual resource positions (Scheutze, 1993; Lev and Sougiannis, 1996). As Deng and Lev (1997: 2) suggest, current accounting practice induces a mismatch in the allocation of costs to revenues, and so misleads observers about the earning capabilities of firms and the true value of their assets. In regards to the valuation of $\mathrm{R} \& \mathrm{D}$, they conclude that '... hundreds of corporate executives, along with their auditors appear to be able to value R\&D and technology in the development stage. This apparent inconsistency between the current regulatory environment which sanctions immediate expending of R\&D and a fast developing business practice, obviously deserves a careful examination...'

Instead, many accounting researchers are now calling for a broad-based effort to develop better measures of how investments in branding, training, and research build important stocks of intangible assets not presently recorded in financial statements - assets that, not coincidentally, are 
said by strategists to build higher reputational assessments among observers (Rindova and Fombrun, 1997; Barney, 1986). Appropriate capitalization of these expenditures would better describe the value of a company's investments in what are fundamentally reputation-building activities.

\section{Towards an integrative view}

Jointly, these five academic literatures suggest that reputations constitute subjective, collective assessments of the trustworthiness and reliability of firms, with the following characteristics (Fombrun and Rindova, 1996).

- Reputations are derivative, second-order characteristics of an industrial system that crystallize the emergent status of firms in an organization field.

- Reputations are the external reflection of a company's internal identity - itself the outcome of sense-making by employees about the company's role in society.

- Reputations develop from firms' prior resource allocations and histories and constitute mobility barriers that constrain both firms' own actions and rivals' reactions.

- Reputations summarize assessments of past performance by diverse evaluators who assess firms' ability and potential to satisfy diverse criteria.

- Reputations derive from multiple but related images of firms among all of a firm's stakeholders, and inform about their overall attractiveness to employees, consumers, investors, and local communities. Simplifying the complex construct of performance helps observers deal with the complexity of the marketplace.

- Reputations embody two fundamental dimensions of firms' effectiveness: an appraisal of firms' economic performance, and an appraisal of firms' success in ful- filling social responsibilities

(Etzioni,

1988; Lydenberg et al., 1986).

Consistent with these characteristics, we therefore propose the following definition (Fombrun and Rindova, 1996): A corporate reputation is a collective representation of a firm's past actions and results that describes the firm's ability to deliver valued outcomes to multiple stakeholders. It ganges a firm's relative standing both internally with employees and externally with its stakeholders, in both its competitive and institutional environments.

\section{OUR DOMAIN ... OUR CHARTER}

The Corporate Reputation Review invites original research that explores the growing convergence between these six academic literatures, between corporate reputation and strategic positioning; corporate identity, communications, and image; branding and profiling; valuation and performance. In particular, we welcome rigorously conducted research, including quantitative, qualitative, experimental, and field studies.

At heart, therefore, the Corporate Reputation Review discourages contributions that are exclusively focused on a narrow disciplinary perspective, whether from advertising, public relations, speech communication, journalism, media studies, organizational analysis, or strategic management. These belong in appropriate specialized publications. Suitable articles should reveal authors' familiarity and understanding with complementary positions in relevant disciplines. For instance, relevant articles might examine how reputations:

- evolve from employee communications through a process of organizational identification;

— relate to a firm's social responsibility and its grassroots management activities; 
- develop from consolidated approaches to marketing, organization, and strategy;

- are orchestrated internally through joint programs for managing investors, employees, customers, analysts, and regulators.

The Corporate Reputation Review also invites contributions from practitioners that address the strategic development and maintenance of corporate reputations. Practitioners' articles will be reviewed by the editors and by members of our Executive Advisory Panel. Topics could include best practice in crisis management, media relations, employee involvement programs, packaging and design, advertising campaigns, strategic reorientations, and their implications for a company's reputation. Occasionally, the Review will also publish relevant book reviews that address important topics related to reputational management.

Ultimately, the Corporate Reputation Review targets a core audience of academics, client practitioners, journalists, and management consultants interested in reputation management. The Review should also be of considerable relevance to senior executives responsible for nurturing and defending corporate reputations. In addition, likely to welcome the Review are professionals whose everyday life revolves around building, maintaining, or defending reputation, be they identified with strategic management, investor relations, public relations, marketing, advertising, employee communications, or public affairs.

\section{THE CONFERENCE ON CORPORATE REPUTATION, IMAGE, AND COMPETITIVENESS-JANUARY 17-18, 1997}

To iniatiate dialogue and celebrate the launching of the Corporate Reputation Review, we organized a conference at the
Stern School of Business at New York University on January 17-18, 1997. The conference was sponsored by the Royal Dutch/Shell group of companies, and brought together a multi-disciplinary group of international scholars and practitioners to discuss their research and experience in the area of reputation management. We organized the presentations around five themes.

- How reputations develop

- How valuable are reputations

- How reputations affect corporate performance

- How reputations have other favorable and unfavorable consequences

- How reputations should be managed in good times and bad times

In this inaugural issue of the Corporate Reputation Review, we capture the essence of the conceptual, empirical, and casebased contributions made by conference participants during their stay in New York. In particular, we asked contributors to abridge and revise their comments for this issue, in the belief that the inaugural issue would have greater impact if it presented a complete picture of the 'reputational landscape'. In so doing, of course, we risk over-simplification: authors' ideas are necessarily less fully articulated than they would otherwise be in more extensive expositions. By encompassing the breadth of sessions in the conference, doubtless we have distorted the individual 'trees' of the reputational forest. We defend doing so here, however, because we believe the benefits of breadth outweigh the costs of depth in this fragmented domain. The inaugural issue therefore clearly emphasizes our common agenda rather than our many differences.

If all goes according to plan, researchers and practitioners will have ample opportunity to articulate more fully their evolving views in subsequent issues of the Corporate 
Reputation Review. As editors, we look forward to helping authors develop their ideas into valuable contributions to knowledge and understanding about corporate reputations. We embark on this challenging journey full of hope and not a little trepidation at the considerable responsibility it will entail. We hope you will join us in this exciting endeavor.

\section{REFERENCES}

Aaker, D. and Keller, K.L. (1990), 'Consumer Evaluations of Brand Extensions', Journal of Marketing, vol. 54, January, 27-41.

Abrahamson, E. \& Fombrun, C. (1992) 'Forging the iron cage: ...' Journal of Management Studies.

Abrahamson, E. \& Fombrun, C. (1992) 'Macrocultures: Determinants and Consequences', Academy of Management Review.

Albert, S. \& Whetten, D. (1985) 'Organizational identity', in L.L. Cummings \& B.M. Staw (Eds.), Research in Organizational Behavior, vol. 7: 263295. Greenwich, CT: JAI Press.

Allen, F. (1984) 'Reputation and product quality', Rand Journal of Economics, v. 15, 311-327.

Bagwell, K. (1992) 'Pricing to signal product line quality' Journal of Economics and Management Strategy, 1, 151-174.

Barney, J.B. (1986) 'Organizational culture: Can it be a source of sustained competitive advantage?' Academy of Management Review, 11: 656-665.

Belch, G.E. and Belch, M.A. (1987) 'The Application of an Expectancy Value Operationalization of Function Theory to Examine Attitudes of Boycotters and Non Boycotters of a Consumer Product', Advances in Consumer Research, vol. 14, 232-236.

Boush, D. and Loken, B. (1991) 'A Process-Tracing Study of Brand Extension Evaluation', Journal of Marketing, vol. 28, issue 1, 16-28.

Brealy, R. and Myers, S. (1988) 'Principles of Corporate Finance', NY: McGraw-Hill.

Brown, T.J. and Dacin, P.A. (1997) 'The Company and the Product: Corporate Associations and Consumer Product Responses', Journal of Marketing, January, 1997, vol. 61, 68-84.

Camerer, C. \& Vepsalainen, A. (1988) 'The economic efficiency of corporate culture' Strategic Management Journal 9: 115-126.

Caves, R.E. \& Porter, M.E. (1977) 'From entry barriers to mobility barriers', Quarterly Journal of Economics, 91: 421-434.

Chakravarthy, B. (1986) 'Measuring strategic perfor- mance', Strategic Management Journal, 7: 437-458.

Cramer, S. \& Ruefli, T. (1994) 'Corporate reputation dynamics: Reputation inertia, reputation risk, and reputation prospect', Paper presented at the National Academy of Management Meetings, Dallas.

Dawar, N. and Parker, P. (1994) 'Marketing universals: consumers' use of brand name, price, physical appearance, and retailer reputation as signals of product quality, Journal of Marketing, 58, 2, 81-95.

Deng, Z. \& Lev, B. (1997) 'Flash-Then-Flush: The Valuation of Acquired R\&D in Process', New York University, Stern School of Business, Accounting Department Working Paper.

DiMaggio, P.J. \& Powell, W.W. (1983) 'The iron cage revisited: Institutional isomorphism and collective rationality in organizational field', American Sociological Review, 48: 147-160.

Dutton, J.E. \& Dukerich, J.M. (1991) 'Keeping an eye on the mirror: Image and identity in organizational adaptation', Academy of Management Journal, 34: 517-554.

Dutton, J. \& Penner, W. (1992) 'The importance of organizational identity for strategic agenda building', in Johnson, G., and Hendry, J. (Eds.), 'Leadership strategic change, and the learning organization'.

Etzioni, A. (1988) 'The Moral Dimension', NY: Free Press.

Fombrun, C.J. (1996) 'Reputation: Realizing Value from the Corporate Image', Cambridge, MA: Harvard Business School Press.

Fishbein, M. \& Azjen, I. (1975) 'Belief, attitude, intention and behavior', Addison-Wesley, Reading, Mass.

Fombrun, C.J. \& Rindova, V. (1996) 'Who's Tops and Who Decides? The Social Construction of Corporate Reputations', New York University, Stern School of Business, Working Paper.

Fombrun, C.J. \& Shanley, M. (1990) 'What's in a name? Reputation-building and corporate strategy', Academy of Management Journal, 33: 233258.

Fombrun, C.J. \& Zajac, E.J. (1987) 'Structural and perceptual influences on intraindustry stratification', Academy of Management Journal, 30: 33-50.

Freeman, R.E. (1984) 'Strategic management: a stakeholder approach', Boston, MA: Pitman Press.

Granovetter, M. (1985) 'Economic action and social structure: The problem of embeddedness', American Journal of Sociology, 91: 481-510.

Grossman, S. \& Stiglitz, J. (1980) 'On the impossibility of informationally efficient markets', American Economic Review 70: 393-408.

Hall, R. (1992) 'The strategic analysis of intan- 
gible resources', Strategic Management Journal, 13: 135-144.

Kapferer, J.N. (1992) 'Strategic Brand Management', Kogan Page, London.

Keller, K.L. (1993) 'Conceptualizing, Measuring, and Managing Customer-Based Brand Equity', Journal of Marketing, vol. 57, January, 1-22.

Klein, B. \& Leffler, K. (1981) 'The role of market forces in assuring contractual performance', Journal of Political Economy, 89: 615-641.

Kotler, P. (1991) 'Marketing Management: Analyses, Planning and Control', 8th ed. Englewood Cliffs, NJ, Prentice Hall.

Lev, B. \& Sougiannis, T. (1996) 'The capitalization, amortization, and value-relevance of $\mathrm{R} \& \mathrm{D}$ ', Journal of Accounting and Economics, 21: 107-138.

Lippmann, W. (1922) 'Public Opinion', New York.

Lydenberg, S.D., Marlin, A.T. \& Strub, S.O. (1986) 'Rating America's corporate conscience', Reading, MA: Addison-Wesley.

Maathuis, O.J.M. and Van Riel, C.B.M. (1996) 'The Added Value of the Corporate Brand', Management Report Series, Rotterdam School of Management, Rotterdam.

McGuire, J.B., Sundgren, A. \& Schneeweis, T. (1988) 'Corporate social responsibility and firm financial performance', Academy of Management Journal, 31 (4): 854-872.

Meyer, A. (1982) 'Adapting to environmental jolts', Administrative Science Quarterly, 27: 515-537.

Miles, R. with Cameron, K. (1982) 'Coffin Nails and Corporate Strategies', Englewood-Cliffs, NJ: Prentice-Hall.

Milgrom, P. \& Roberts, J. (1986) 'Relying on the information of interested parties', Rand Journal of Economics, 17: 18-32.

Myers, S., \& Majluf, N. (1984) 'Corporate financing and investment decisions when firms have information investors do not have', Journal of Financial Economics, 13.

Nayar, P.R. (1990) 'Information Asymetries: A Source of Competitive Advantage for Diversified Firms, Strategic Management Journal, 11, 513-519.

Olins, W. (1978) 'The Corporate Personality, Thames and Hudson, London.

Park, C.W., Milberg, S. and Lawson, R. (1991) 'Evaluations of brand extensions: the role of product feature similarity and brand concept consistency', Journal of Consumer Research, 18, 2, 185-193.

Petty, R.E. and Cacioppo, J.T. (1986) 'Communication and Persuasion: Central and Peripheral
Routes to Attitude Change', Springer Verlag, New York.

Poeisz, T.B.C. (1988) 'The Image Concept: its place in consumer psychology', Journal of Economic Psychology, 10, 457-472.

Porac, J.F. \& Thomas, H. (1990) 'Taxonomic mental models in competitor definition', Academy of Management Review, 15: 224-240.

Rao, A.R. and Ruekert, R.W. (1994) 'Brand alliances as signals of product quality', Sloan Management Review, Fall, 87-97.

Rindova, V. \& Frombrun, C.J. (1997) 'Constructing Competitive Advantage', Strategic Management Journal, forthcoming.

Ross, S.A. (1977) 'The determination of financial structure: The incentive-signalling approach', Bell Journal of Economics, 23-40.

Scheutze, W. (1993) 'What is an Asset?' Accounting Horizons, Vol. 7.

Schultz, D.E., Tannenbaum, S.I. and Lauterbron, R.F. (1994) 'Integrated Marketing Communication', NTC Books, Chicago.

Shapiro, C. (1983) Premiums for high-quality products as returns to reputations', Quarterly Journal of Economics, 98: 659-681.

Shapiro, S.P. (1987) 'The social control of impersonal trust', American Journal of Sociology, 93: 623-658.

Shrum, W. \& Wuthnow, R. (1988) 'Reputational status of organizations in technical systems', American Journal of Sociology, 93: 882-912.

Stigler, G.J. (1962) 'Information in the labor market', Journal of Political Economy, 1962, 70: 49-73.

Stiglitz, J.E. (1989) 'Imperfect information in the product market', in Schmalensee, R. \& Willig, R. (Eds.), 'Handbook of Industrial Organization', Chapter 13: 769-847, Amsterdam, Holland: North-Holland Press.

Wartick, S.L. (1992) 'The relationship between intense media exposure and change in corporate reputation', Business \& Society, 31: 33-49.

Weigelt, K. \& Camerer, C. (1988) 'Reputation and corporate strategy: A review of recent theory and applications', Strategic Management Journal 9: 443-454.

White, Harrison C. (1981) 'Where do markets come from?' American Journal of Sociology, 87: 517-547.

Wilson, R. (1985) 'Reputations in games and markets' in Roth, A.E. (Ed.), 'Game-theoretic models of bargaining', Cambridge University Press. 
Reproduced with permission of the copyright owner. Further reproduction prohibited without permission. 